\title{
Boulevard to broken dreams, Part 1: the Polonoroeste road project in the Brazilian Amazon, and the World Bank's environmental and indigenous peoples' norms
}

\author{
O projeto de estrada Polonoroeste na Amazônia brasileira, e as \\ normas ambientais e dos povos indígenas do Banco Mundial
}

ROBERT H. WADE*

\begin{abstract}
RESUMO: O projeto de estrada Polonoroeste na Amazônia brasileira, e as normas ambientais e dos povos indígenas do Banco Mundial. Ao final de 1980 o Banco incorporou as normas de sustentabilidade ambiental e proteção dos povos indígenas e foi seguido por outras organizações interestaduais orientadas para o desenvolvimento. Este artigo de duas partes descreve como uma luta sobre o projeto da estrada Polonoroeste na Amazônia brasileira - dentro do banco, entre o Banco e ONGs apoiadas pelo Congresso dos EUA, e entre o Banco e o governo do Brasil -ajudou na mudança de normas políticas de longo alcance. A primeira parte descreve como o projeto foi concebido como uma inovação no desenvolvimento sustentável em florestas tropicais; e como ela provocou um alvoroço dentro do Banco enquanto se movia em direção a aprovação do projeto.

PALAVRAS-CHAVE: Política de normas; florestas; povos indígenas; Banco Mundial; ONGs ambientalistas; governo do Brasil; Congresso dos EUA.
\end{abstract}

ABSTRACT: Before the mid 1980s the World Bank conceived "nature" as something to be "conquered" and "environment" as a source of resources for "development". By the late 1980s the Bank incorporated norms of environmental sustainability and indigenous peoples' protection into its mandate, and other development-oriented IOs followed. This two-part paper describes how a fight over the Polonoroeste road project in the Brazilian Amazon inside the Bank, between the Bank and NGOs supported by the US Congress, and between the Bank and the government of Brazil -helped to generate the far-reaching change of policy norms. The first part describes how the project was designed as an innovation in sustainable development in rainforests; and how it provoked a firestorm inside the Bank as it moved towards project approval.

KEYWORDS: Policy norms, rainforests; indigenous peoples; World Bank; environmental NGOs; government of Brazil, US Congress.

JEL Classification: Q5; O13; I3.

\footnotetext{
* Robert H. Wade is professor of political economy at the London School of Economics. E-mail: R.Wade@lse.ac.uk. Submitted: 13/February/2015; Approved: 17/April/2015.
} 


\section{INTRODUCTION $^{1}$}

Inter-state organizations (IOs) are steered by policy norms -shared expectations of all relevant actors about what constitutes appropriate policy prescription for a particular sector. In any sector there are many potential norms about appropriate policies (for forests, indigenous peoples, management of the capital account, tax structure, gender); but IOs have an inner imperative to crystallize out only one set of norms and codify that set in policy documents and operational procedures. Once this codification is achieved the norm starts to exert "structural power" on the behaviour of IOs and on international policy more generally. But most of the International Relations literature which emphasises the structural power of norms to shape action takes the existence of norms as the starting point, and says little about the process by which the norms emerge and then stabilize (and later perhaps decline, in a norm cycle).

The literature tends to imply a linear path of cumulative learning, from ignorance towards knowledge, and to ignore the fights over differing norms. For example, the magisterial history of the World Bank by Edward Mason and Robert Asher says next to nothing about fights over norms and policies; it describes only the end results. ${ }^{2}$

This essay explains the emergence of norms about environmental protection and indigenous peoples' protection in the World Bank. Before the mid to late 1980s the Bank conceived "nature" as something to be "conquered", and "environment" as a source of "resources" for "development". Protection of the environment (beyond what was required for good engineering practice or good agronomy) was for the United Nations Environment Program or someone else to take care of. Protection of indigenous peoples was for the borrower government. Once the Bank incorporated norms of environmental sustainability and indigenous peoples protection into its own mandate in the late 1980s, other development-oriented IOs followed. The Bank was the first mover.

Political scientists writing about the emergence of environmental norms in the World Bank have emphasised the role of external agents in forcing the Bank to change its mind, especially US NGOs. The latter took ideas already codified for the United States, and used their access to Congress to get it to use its control of US financing for the Bank as a lever. As Susan Park says, "In terms of the World Bank's

\footnotetext{
1 This article is based on field work inside the World Bank in 1995-96 for the World Bank History Project. It is an extended version of Wade's account of Polonoroeste in "Greening the Bank: the struggle over the environment, 1970-1995”, in Devesh Kapur, John Lewis and Richard Webb (eds), 1997, The World Bank: Its First Half Century, Brookings, vol. 2. Maritta Koch-Weser provided useful comments on an earlier draft.

${ }^{2}$ Mason, Edward and Robert Asher, (1973), The World Bank Since Bretton Woods. Washington DC: Brookings.
} 
environmental actions, it is well documented that external pressure has overwhelmingly, although not exclusively, influenced the Bank.... The idea of protecting the natural environment emerged within the World Bank in the 1980s with the 'do no harm' principle after [external] environmentalists documented large-scale, highprofile, environmentally disastrous Bank projects". ${ }^{3}$

It is true that from the mid 1980s onwards environmental NGOs launched campaigns against the World Bank and some of its borrower governments. They selected particular projects for scrutiny, aiming to reveal publicly that the projects were having damaging effects not admitted by the Bank, and thereby convince the Bank's shareholders that the organization needed institutional reform. The NGOs were mostly American, and they worked through public media and the US Congress to force the Bank to change its norms and procedures.

However, this version of the history underplays the internal organizational structure of the Bank, the internal debates over appropriate environmental and social ideas, and the way that internal norm advocates frustrated by internal obstacles gave the external advocates information (oxygen). This is particularly true of Polonoroeste ("Northwest Pole"), in northwest Brazil, the first project to attract serious criticism of the Bank from the US government, US NGOs, and the US public. Polonoeste was a point of transition for the whole of the Bank, after which senior managers came to agree that the organization had to change some of its key ideas, structure and procedures.

The Polonoroeste project aimed to pave an existing 1,500 kilometer dirt road from the densely populated south central region into the sparsely populated Amazon, in the states of Mato Grasso and later Rondonia. The planners justified the road in terms of assisting already settled families in this part of Amazonia and helping establish new arrivals in farms and settlements, while also keeping them out of (to be) demarcated ecological and Amerindian zones. The affected area was the size of Ecuador, California, or Great Britain. The Bank approved five loans in support of Polonoroeste between 1981 and 1983, totaling \$457 million. Well over half went for the highway and feeder roads. The Bank was the only non-Brazilian source of finance. ${ }^{4}$

The Northwest Region Integrated Development Program, to give its full English name, was conceived in the Bank not as a routine project but as gamechanger. The project team designed it as a project that would give unprecedented attention to mitigating adverse effects on the environment and on indigenous peoples. Whereas the Brazilian government was mainly interested in Bank help with

\footnotetext{
3 Susan Park (2010) “The World Bank's global safeguard policy norm?”, in Susan Park and Antje Vetterlein, Owning Development: Creating Policy Norms in the IMF and the World Bank, Cambridge University Press, at 182, 183-4, emphasis added.

${ }^{4}$ World Bank, "World Bank Approaches to the Environment in Brazil", vol. V, "The Polonoroeste Program”, OED Report 10039, SecM92-64, April 30, 1992.
} 
the highway (on which construction had been started earlier by the military), the Bank wanted to use its money to induce the government to agree to a model of comprehensive, sustainable regional development in rainforest areas, which could be applied in other parts of the world.

The irony is rich. Starting in 1983 and continuing till 1987 US NGOs used Polonoroeste as their trampoline for demanding changes in Bank policy. In a crescendo of articles, television documentaries and hearings before US congressional committees, the Bank's environmental critics held up Polonoroeste as "the Bank's biggest ... and most disastrous involvement in forest colonization in the tropics", the quintessential example of its pursuit of misguided development strategies. ${ }^{5}$ Polonoroeste offered powerful images of palls of smoke, bulldozed trees, blackened stumps. It presented a saga of victims and villains, of immiserized peasants and state-of-nature Amerindians squashed by military governments, rapacious loggers, and multilateral banks. The Sierra Club's indictment of the World Bank and other multilateral development banks, called Bankrolling Disasters, featured on its cover a color photograph of a newly cleared forest in Polonoroeste, with the caption, "A typical scene of destruction as development advances in the Amazon". ${ }^{6}$ The British journal The Ecologist, whose brand of political ecology carried a strong critique of existing development models, published a special issue called The World Bank: Global Financing of Impoverishment and Famine, with articles on Polonoroeste. ${ }^{7}$ Sixty Minutes, the most widely watched US television newsweekly at the time, featured Polonoroeste in a 1987 documentary sharply critical of the World Bank for wasting US taxpayers' dollars. For periods after these and other denunciations appeared, dozens, sometimes hundreds of protest letters arrived at the Bank president's office every day. Chain-sawed tree trunks and displaced Amerindians became poster-children of the environmental movement. Many people who had never heard of the World Bank came to know it as "the bank that destroys rainforests".

Suddenly the Bank found itself defined as doer of harm and teller of lies, and required to react to outsiders' ideas about how it should do its business. For an organization that had always prided itself on its service to humanity and unrivalled technical expertise, this was bewildering.

When Barber Conable, the president of the Bank, announced a major expansion of the Bank's environmental capacity in 1987 he gave special attention to Polonoroeste. It was, he said,

\footnotetext{
${ }^{5}$ Bruce Rich (1985) "Multi-lateral development banks. Their role in destroying the global environment", The Ecologist, vol. 15, no. 1/2, p. 59.

${ }^{6}$ Sierra Club, Bankrolling Disasters: International Development Banks and the Global Environment, Washington DC: Sierra Club, 1986.

${ }^{7}$ The Ecologist, “The World Bank: Global Financing of Impoverishment and Famine”, vol. 15, no. 1/2 (1985).
} 
"a sobering example of an environmentally sound effort which went wrong. The Bank misread the human, institutional and physical realities of the jungle and the frontier. In some cases, the dynamics of the frontier got out of control. Protective measures to shelter fragile land and tribal people were included; they were not, however, carefully timed or adequately monitored". ${ }^{8}$

"The Bank misread...the realities", said Conable. But who is the Bank? Long before environmental NGOs began to focus on it the project had become controversial inside the Bank. The NGOs took it as their spearhead partly because a few of the project's internal critics brought it to their attention and gave them information. From the beginning some staff argued that the Bank should stay away from the project because the risks were too high and better alternatives for agricultural development existed elsewhere in the northern part of Brazil. The internal disputes gave rise to what one participant called "a turbulent and traumatic evolution during its preparatory phases", referring to "the many controversies that marked its slow progress through the Bank".

The Bank eventually suspended financial disbursements for the project in response to the NGO campaign and the evidence of environmental and social damage the campaign forced the Bank to recognize - the first time in the Bank's history that it had suspended disbursements on such grounds. It resumed disbursements only after it was satisfied that the Brazilian government had made at least some progress on its commitments.

Hence the Polonoroeste project has a seminal role in the history of how the Bank moved from saying that development and environment are two different fields, to saying "Our mandate is economic growth, poverty reduction and environmentally and socially sustainable development"; and also a seminal role in the interwoven politics of how it moved from saying "We are accountable only to our shareholders (member governments), and NGOs can convey their views to us only through the relevant Executive Director on the Board" to saying "We are concerned to reach out to civil society organizations and learn from what they have to say".

This essay describes the project's "turbulent and traumatic evolution" inside the Bank, highlighting relationships between (a) the operational staff with direct project responsibility, located in the regional vice presidencies, (b) the technical experts located in the Central Projects Staff (the "curia" for the operational divisions), and (c) the senior management. Through these relationships one sees how the organization was addressing "green" issues and "social" issues before it had dedicated staff, organizational units, and operational procedures to address them.

\footnotetext{
${ }^{8}$ Barber Conable, speech to World Resources Institute, May, 1987.

${ }^{9}$ James Lee (PASEN) to Mr V. Rajagopalan, Director, PAS, August 4, 1983.
} 
Long before the Bank established formal regional environmental divisions and a central environment department in 1987 , technical experts in the center were pressing environmental and social issues. But when project leaders in the regional vice presidency, backed by senior management, were determined to get the project approved by the Board and dispersing funds (getting projects approved by the Board was the metric of project staff's career success), the technical advice could be largely ignored if it would slow down the project or raise costs. The technical experts in the central complex saw themselves having to deal with the regional project staff sometimes as diplomats and sometimes as guerrillas.

Adding to the thin body of literature on how development-oriented IOs work on the inside, the essay illustrates intra-Bank and Bank-country interactions at the "emerging" stage of norm formation, before the relevant norms stabilize and acquire formal validity in the form of policy papers and operational directives. From the events described here came an elaborate set of formal norms by the late 1990s, in the shape of "safeguard policies" covering environment, indigenous peoples, resettlement and other domains, which had in common that the Bank was exposed to high reputational risk in all of them.

\section{FIRST STEPS}

In 1900, over 80 percent of Brazilians lived near the sea-“crabs clinging to the coast", as they were once described. The population and economy have been drifting towards the interior ever since, especially after the relocation of the capital to Brasilia in 1960, in central Brazil. By the late 1960s the Brazilian state expanded strategically into Amazonia, initially by building the Transamazonia East-West Highway and associated resettlements.

By the early 1970s the military was building a gravel road (Highway 364) into the northwest Amazon. The fast economic growth of the late 1960s and early 1970s-when Brazil was the "economic miracle"-fuelled a nationalist mood that prioritized integrating unoccupied areas and their purported natural wealth with the rest of the country, lest they be cannibalized by foreign enterprises or foreign governments. In 1970 the country's military rulers announced a "plan for national integration" that involved the planned settlement of Rondonia. A key part of the plan called for as many as five million peasants to be settled on tracts of virgin Amazon soil by 1989 , making it potentially the most ambitious colonization effort undertaken in the Americas since the opening of the American West a century before. The World Bank was not asked to participate, because the military government regarded the plan as a matter of national security which foreigners should not be involved in.

Transport along the unpaved road remained difficult, and during the rainy season almost impossible. Promised support to the new settlers did not materialize. 
Most of the pilot colonization settlements failed. With a change of government in 1974 the organized settlement program was abandoned, while unorganized settlement continued. By 1979 newspaper reports on the plight of the stranded settlers from the 1970-74 scheme were describing Rondonia as "a land of absolute and total desperation". A Washington Post story in 1979 said, "elected officials, church leaders and technicians here charge that Brazil's Amazon's pioneers are victims not so much of the frontier's inevitable ruggedness as the Brazilian government's lack of planning and the constant zig-zags in its Amazon development policy". ${ }^{10}$

The new Brazilian government of the late 1970s wished to resuscitate the project. It saw Polonoroeste as a way to achieve several national security and economic goals at once: to fill up the "demographic desert" of the Amazon with Brazilian citizens so as to consolidate its territorial jurisdiction; create a new source of foreign exchange earnings from tree crops; and reduce unemployment and pressure on land elsewhere in Brazil. Unemployment and land pressure were related to Brazil's extremely unequal income distribution. The government, reflecting elite interests in the wealthy south, promoted a shift from small-scale peasant agriculture to large-scale export production. It gave generous tax and credit subsidies for land clearing, cattle breeding and labor-replacing mechanization. It saw the Amazon frontier as a conflict-reducing vent for the resulting displaced population.

Unlike many Bank projects this one was initiated by the borrower: the government sought out the Bank. The Brazilians were already receiving large Bank loans for the maintenance and rehabilitation of existing highways, and they wanted Polonoroeste to be just another road rehabilitation project. The Bank responded positively, and the Latin America Highways Division sent out a project preparation mission in 1978. The mission found that migrants by the truckload were arriving every day-only to fall into a poverty trap, unable to buy inputs or market outputs because of the poor state of the roads, said the Brazilians and the Bank.

But the Bank staff saw the need for more than roads. They argued that, (1) Brazil would pave the highway and build the feeder roads whether the Bank helped or not; (2) with the highway made into an all-weather road still more migrants would flood in; (3) the Brazilian government was engaged in planning settlements on the basis of geometrical grids that ignored soils, water, and slope, with results repeating the 1970-74 failure; so (4) Bank help in preparing a wider regional development scheme would ensure that more was done on the ground to make the settlements viable and to protect the environment and Indians. From this perspective the Bank saw the road project as the entry price for a complex regional integrated rural development program. The Bank was by then, around 1980, promoting integrated rural development (IRD) projects all over the world. IRD was the fashion. IRD could be applied in the Amazon, said the Bank.

\footnotetext{
${ }^{10}$ Larry Rohter, "Hopes of Amazon pioneers dashed in nightmare of misery", Washington Post, January 28,1979 , p. A $24-25$.
} 
Processing the highway loan was suspended for a year while the Bank sent out a further fact-finding mission in late 1979. The mission's report of 1980 concluded that the region did have big agricultural potential and that the rate of return to the project investment would be very high. It also concluded that careful steps had to be taken to mitigate environmental and social costs-including malaria, deforestation, extinction of species, and the impoverishment or death of the Amerindian inhabitants, whose numbers were estimated, at first, at 5,000.

The steps for mitigating environmental damage included (1) land-use zoning, (2) the development of cropping patterns and practices thought suitable to the fragile and variegated soils, (3) the demarcation and gazetting of reserves, and (4) detailed soil mapping, to steer the migrants away from areas of low agricultural potential. These same steps would help protect the Amerindian populations; but there was also a special program for Amerindian protection, including the creation of special reserves, special health care and related measures called for in Brazil's existing legislation on indigenous people but not enforced.

One geographical feature guaranteed that the venture would be difficult. The markets for the bulk of the agricultural produce were in the south at the start of the highway, while the patches of good soils were mostly in the north at the far end of the highway. The long tract in between was thought to have mostly poor soils, unsuitable to sustained annual cropping but perhaps suitable for tree crops. Yet the migrants would probably not wait till they got to the good northern soils; they would head for land closer to the start, burn the forests and-not having enough savings to invest in tree crops-plant annual crops. If the soils could not support annual crops, the migrants would move to another place, chop down more forest and start again. Without enforced zoning, deforestation and immiseration of the forest-dwelling Amerindians would result.

\section{PROJECT PREPARATION}

The project had a powerful champion in the Bank who saw Polonoroeste as a model for the development of "the world's last land frontier" and also as his own contribution to history. Robert Skillings, chief of the Brazil country programs division from 1971 to late 1982, had joined the Bank in 1947, by the time of his retirement in the late 1980s being the longest-serving Bank staff member ever. He was then one of the highest profile division chiefs in the Bank, with a reputation as "a complex character, an extremely forceful personality, someone who struck fear into the hearts of subordinates", in the words of a colleague. By the late 1970s the Amazon was his passion. During a sabbatical year in 1978/79 at the nearby Johns Hopkins School of Advanced International Studies in Washington DC he spent much of the time researching and teaching about the Amazon, visiting the region 
several times and co-authoring a book about it. ${ }^{11}$ Market exploitation of the Amazon was inevitable, he said; the only question was whether it happened wisely or in the free-for-all anarchy of the American West. The Bank could help to ensure that this global asset was developed wisely.

From the start Skillings took the project as his own, notwithstanding that he was division chief in the programs hierarchy of the Latin American vice presidency, not the projects hierarchy. It was unusual for a programs division chief to take this kind of role in a project. At the top, President McNamara signaled keen support for Skillings and the project. He wanted the Bank to do more to reduce poverty in Northeast and Northwest Brazil. He also loved complex, integrated projects that promised heroic transformation.

The fact finding mission of late 1979 comprised nine people. The members disagreed about what the Bank should do. Robert Goodland, a tropical ecologist in the Bank's tiny Office of Environmental Affairs, argued that the risks of jungle settlement were simply too high. The Bank should rather focus on the development of the savannah (cerrado) of central Brazil, an area nearly as big as the Amazon, relatively empty of people, whose development would not involve cutting tropical forests and exposing fragile soils, whose climate was more suitable to agriculture, and whose location was closer to major markets. He had done extensive field research in both the Amazon and the savannah before joining the Bank, so he had expert knowledge. ${ }^{12}$ After the fact finding mission he was not invited near the project again.

Other members of the mission, especially the transport economist, urged the Bank to go slow on the highway project for a year or two while efforts were made to help the Brazilians do some of the foundations for the agriculture, environment, Amerindian and health components-to do proper soil and cadastral surveys, for a start.

On the reconnaissance mission they realized, as they had not before, that the road would go through the lands of vulnerable Amerindian tribes. The mission leader brought up the issue with Brazilian officials. The result was a shouting match. "There is no way the Bank will be involved in Amerindian protection", said the Brazilians. They regarded Amerindian protection as a national security issue, no more appropriate for the Bank than it would be for the Brazilian government to tell the US Federal Bureau of Investigation how to do its business.

Skillings joined the mission for a debriefing session at the end. Around a hotel dinner table he asked each member to state their conclusions about the project.

\footnotetext{
${ }^{11}$ Robert Skillings and Nils Tcheyan, 1979, Economic Development Prospects of the Amazon Region of Brazil, Washington DC: Center for Brazil Studies, School of Advanced International Studies, The Johns Hopkins University.

${ }^{12}$ R. Goodland and M.G. Ferri, Ecologia do Cerrado, São Paulo: University of São Paulo Press, 1979, and R. Goodland, The Amazon Jungle: Green Hell to Red Desert, Elsevier Academic, 1975.
} 
Most urged either that the Bank stay out or that the road component be delayed while the other things were started. Skillings was angry. Yes, he said, the project was risky, but it would be worse if the Bank were not involved. A decision not to get involved would anger the Brazilian government and his own senior management, both of which were expecting the project. He declared that the project would proceed. The government was not interested in borrowing for an altered sequence, he said, and in any case agricultural improvement without the road-without good access to markets-was infeasible. The mission report misrepresented Skillings' views as the mission's consensus.

The work of project preparation was divided into three components, one for roads, one for agriculture, one for health. The road and health components were carried out quite separately, little connected to each other or to the agriculture component. Together the project staff spanned five divisions. There was no overall project leader in a substantive sense (only a loan officer who provided administrative coordination). Skillings came as near to playing the role of project leader as anyone, but he had the whole of the Bank's dealings with Brazil to manage.

The agriculture component included the agricultural settlements and the ecological and Amerindian reserves. Five people spread across three sector divisions, one of them half time, worked on the agriculture component. They were mostly idealistic and young (late 20s and early 30s). They regarded themselves as innovators, charged with taking the Bank into the unknown territory of environmental protection, indigenous people's protection, and appropriate agricultural methods in tropical rainforests. They had lively debates among themselves.

Much of the technical work on the agricultural side was done by people in the World Bank-FAO Cooperative Program, based at FAO headquarters in Rome. Between 1979 and mid-1981 the World Bank-FAO Cooperative Program sent out ten missions to help prepare the three agricultural sub-projects, each mission of three to four people lasting about three weeks. One even included a butterfly specialist. There was certainly no skimping on technical input into project design. The job of these people was to show what could be done, technically, assuming a wellordered world with bona fide government officials.

Early on Skillings did make an attempt to involve an outside expert in the Amerindian protection component. This was David Maybury-Lewis, professor of anthropology at Harvard and president of Survival International. Maybury-Lewis recommended the Bank employ the anthropologist David Price as consultant, who had worked extensively in the area. At the end of his employment Price broke confidentiality agreements and went public with savage criticisms of the Bank. ${ }^{13}$ This, together with the Brazilian government's attitude, confirmed Skillings in his

\footnotetext{
${ }^{13}$ David Price, Before the Bulldozers: The Nambiquara Indians and the World Bank, Washington DC: Seven Locks Press, 1989.
} 
conviction that the Bank should stay away from NGOs and other so-called experts, and away from Amerindian protection.

Hence the project leaders strongly discouraged the staff from having even informal contact with non-governmental groups knowledgeable about the Amazon, in Brazil or in the US. Later, Maritta Koch-Weser, at the beginning of her work on the Amerindian protection component, arranged for a meeting with NGOs and the Church. But the NGOs treated her, representing the Bank, as Devil Incarnate, and scripted newspaper articles to the effect that the Bank was trying to "co-opt" the NGO community. Meanwhile, Skillings was furious at her for having made the contact at all.

By and large, the Bank's knowledge about the situation came from a small number of people located in the Bank, in FAO, and in the Brazilian government. It undertook no analysis of the politics of the region and no analysis of the capabilities of the public agencies on the ground.

\section{THE INTERNAL VORTEX}

As project preparation proceeded Polonoroeste was boosted as one of the Bank's flagship projects. But many Bank officials expressed worries. Robert Goodland, who rang the alarm bell on the first reconnaissance mission, was not invited back but nevertheless followed it closely from the sidelines. The transport economist, responsible for the economic analysis of the highway, continued to urge that the Bank not go ahead with the highway until more of the other things were in place; and said that rail and river transport alternatives should be examined too. At project appraisal he made this argument forcibly and was kicked off the team, then dispatched to one of the Bank's dumping grounds, the Operations Evaluation Department. Skillings had his contribution to world history to protect, all the more so because he was approaching retirement.

Other critics in the central Office of Environmental Affairs and the central Agriculture and Rural Development Department continued to speak out. James Lee, the Bank's environmental advisor, reported in a January 1980 memo to his director, "Any Amazon basin development is likely to be closely scrutinized and we feel the Bank would be open to severe criticism, unless great care were exercised in project formulation and implementation to avoid serious environmental repercussions. We feel that the currently used agricultural production system in land settlement and development areas do not offer a sustainable livelihood for farmers and settlers on any but the best 'terra roxa' soils....[The other alternatives proposed are all unproven.] To use unproven technologies as a basis for agricultural settlement under 
extremely adverse soil conditions would be a highly risky undertaking and could prove disastrous for the settlers themselves." ${ }^{14}$

Lee's memo emphasised the thinness of knowledge about soils in the area. Indeed, the only soil data came from the results of a brief and unsystematic FAO survey some years before. The project team did not plan to get more, partly because it would take too long.

Senior people in the powerful Agriculture and Rural Development Department, in the central complex, added their warnings. In early 1980 one said that the project's harmful effects would include "deforestation, particularly of lands unsuitable for sustained agriculture, use of unsustainable agricultural production systems, and the invasion of tribal reservations". Even if the Bank limited its financial support to the rehabilitation of existing settlements [this was one option being considered], it would be seen as supporting the total program. "In such a case we, along with the Brazilian Government, might be considered responsible for allowing indigenous people in the area to be deprived of their lands, exposed to fatal epidemics, and to be socially, morally and culturally degraded....I suspect that the Government's unwillingness to have the Bank involved in any 'Amerindian' programs or contacts is a portent of what may be in store!". ${ }^{15}$

Yet a well-advanced project report, July 1980, retained the earlier optimism about agricultural potential. Reviewing the report, Bank agricultural experts in the Agriculture and Rural Development Department reiterated their earlier warnings. Said one, "Very little is known about the land capacity, ground surveys having been limited to areas of relatively easy access.... The scarcity of information is well reflected in the fact that discussion of the basic resource for any agricultural development-the soils and land capability-is limited to a half a page, together with [a table]".

The reviewer of the Green Cover project report went on to observe that "the problem of enforcement is neglected. This seems to be a crucial issue. If the expected large influx of settlers occurs, can they all-or at least a very large proportion-be guided to settle lands which are capable of sustained productivity? How will settlement of other lands be avoided short of using a large armed policing force? If settlers on unsuitable sites and in forest reserves are to be evicted and given priority for alternative holdings, this could be an incentive to settle such areas as a means of getting on a priority list." He concluded, "The tone of overall optimism does not seem warranted....it seems far from certain, at present, that the Northwest Region will either prove capable of sustaining any very significant volume of exports out of the region, or providing a sustained livelihood for the an-

\footnotetext{
${ }^{14}$ James Lee (OEA) to V. Rajagopalan (CPSVP), January 8, 1980, emphases added.

${ }^{15}$ J.C. Collins (AGR/CPS) to R. Goodland (PAS), February 25, 1980, emphasis added.
} 
ticipated large number of poor settlers without requiring a large and continuing Government subsidy." ${ }^{16}$

Meanwhile, one of the main champions of the project himself concluded from a mission to examine the capabilities of the Amerindian protection agency on which the Bank was relying to implement key safeguards, "FUNAI is presently a weak institution, demoralized by the ongoing dissension between administrators and technical staff. This conclusion is more or less universally accepted in Brazil, as is the feeling that a thorough restructuring of FUNAI is urgently needed. Such a restructuring... will be a long-term proposition and, thus, the Bank should be prepared to accept considerable risk in the interim if it decides to continue its association with FUNAI". ${ }^{17}$

A soil and agricultural production specialist wrote a withering critique of the project report, especially its near total neglect of soil quality and drainage. $\mathrm{He}$ concluded: "In my view, the investigation of lands is presently inadequate to justify the Program". ${ }^{18}$

In short, the internal critics said the decision to go ahead would reflect an inadequate knowledge of soils, an underestimation of the environmental and social risks, and an overestimation of the willingness and ability of government agencies to implement their commitments. They also said there were better opportunities for Bank involvement elsewhere in northern Brazil. Experts from the World BankFAO Cooperative Program in Rome tended to agree. Indeed they were the source of some of the information that the internal critics kept putting to Skillings.

\section{LOAN APPROVAL, 1981}

In the face of persistent criticisms of the project from the Central Projects Staff, Brazil Programs Division Chief Skillings remained unmoved. At a meeting with a few of the critics in November 1980, "Mr Skillings was of the opinion that the Bank's presence in the proposed development scheme was important to obtaining consideration of the environmental and tribal peoples issues. He admitted that it was not likely that all the recommendations made with regard to both issues would be implemented, but felt that even partial consideration and implementation were sufficient to warrant the Bank's participation". ${ }^{19}$

Much of what the Bank was doing, he said, was simply to get the Brazilian

\footnotetext{
${ }^{16}$ J.C. Collins (Advisor, Irrigated Field Crops, AGR/CPS) to D. Mahar (Economist, LC2), July 9, 1980, first emphasis added, second ("given priority...") emphasis in original, third added.

${ }^{17}$ Dennis Mahar (Economist, LC2DA) to Robert Skillings, Division Chief, LC2DA, July 7, 1980.

${ }^{18}$ W.B. Peters to J.C. Collins, AGR, dated July 21, 1981.

${ }^{19}$ James Lee, to Files, November 25, 1980.
} 
government to follow its own legislation on the protection of peoples and areas adversely affected by development projects, in a political situation in which no powerful interests within Brazil wished the legislation to be enforced. He related how at a meeting with the head of the main coordinating body for Polonoroeste within the Brazilian government he had tried to bring up the need for Amerindian safeguards. As he spoke the head of the coordinating agency had reared back in his chair, clasped his hands over his ears, and said, "Please, please, don't bring up Indians". The Bank's involvement in the protection of Indians would just invite trouble from the array of Brazilian interests that had no wish to protect them, said the official.

Indeed, at a later meeting, Skillings himself distanced the Bank from Indian protection. "The World Bank was above all else an economic development institution and should not align itself with or 'take up' a cause such as the [tribal peoples' issue]. He cited drugs, urban crime, etc., as causes which could also merit the Bank's attention." 20

In April 1981 the Loan Committee (of the operational vice presidents) met to discuss the decision to proceed to negotiations with the Brazilians (about phase I, the biggest component of the three phase program). This was the last point in the process where the project could, in practice, be turned back or modified; once approved for negotiations the project was very likely to be approved by the Board. The representatives from the Latin America region (not the central departments which had been the seat of opposition) "explained that existing information confirms that adequate soils and appropriate cultivation techniques are available for agricultural development of the Northwest Region". ${ }^{21}$ They also said that the Bank could be reasonably confident that the new settlements would be confined to areas with soils that could support them, because "areas of unsuitable soils have in the past normally been shunned even by spontaneous migrants".

The minutes record that members of the Central Projects Staff "expressed concern" that, "in the absence of land use planning and enforcement", unsuitable soil areas would "increasingly be invaded for shifting cultivation of food crops leading to rapid environmental degradation". But the central Agriculture and Rural Development (AGR) Department had already signed off on the project, fundamental objections notwithstanding. By this time the project had too much momentum behind it for it to be redesigned, especially given McNamara's and Skillings' commitment. And the project statement had indeed been modified to take partial account of AGR concerns. The text said more forcefully than before that the sites of new settlement would only be in areas of good soil-but left unanswered the AGR

\footnotetext{
${ }^{20}$ James Lee, to Files, December 19, 1980, emphasis added.

${ }^{21}$ Loan Committee minutes of meeting to consider the Northwest Region Development Program and First Stage Project held on April 15, 1981, dated May 7, 1981, all emphases added, here and in the later quotes.
} 
points that (1) no one knew where the good soils were, and (2) no enforcement mechanism existed to channel people towards them.

On the issue of Indian protection Ernest Stern, the chairman of the meeting and the senior operational vice president (number two in the Bank after McNamara), "inquired whether any participant in the meeting felt that the Bank was not doing anything it should be doing. The general view", the minutes continue, "was that the proposed measures were satisfactory but that close monitoring of their implementation would be required, especially given the fact that the issue was controversial and that the Bank would undoubtedly continue to be subject to criticism."

The environmental advisor suggested that the Bank should meet with outside critics of the project "in order to fully share facts and views on the steps being taken...to protect the interests of the Amerindian population, in an effort to defuse what is a highly charged emotional issue". The Latin American region said no. "The Region observed that some of the positive results obtained on this matter were made possible by the atmosphere of mutual confidence that prevailed in our discussions of the matter with the Government, and ... caution was required in making public the results of these discussions." In reply, "the Environmental Advisor said that the critics could be expected to take their case to the governments of several of the Bank's important donor countries". This was an early warning of what was to come.

Stern proposed that the region should respond to the critics by placing an article on the whole program, including the Indian issue, in Finance and Development (the Bank/Fund quarterly); and arrange "appropriate discussions on the topic with the members of the Board [not outside critics] in due course". A modest proposal.

During the meeting Stern several times raised the question of whether the Brazilian federal and state government had the capacity to carry out the plans. "Shouldn't we wait till we have better data about soils?", his assistant asked the project staff. Answer: "We have put in a provision for agro zoning to be done before the road reaches that point". "What happens if the road gets there first?". Answer: "That won't happen".

Late in the one and a half hour meeting a vice president asked for the floor, leaned back in his chair, folded his arms, and said, "What we are really saying is, The Government of Brazil is willing to sign its name to a legal contract that it will undertake certain obligations. Do we believe it, or do we not? If all the provisions are in the legal contract, then the only basis for not going ahead is that we don't believe that the government is credible when it signs an internationally-binding agreement.'" He implied that the Bank could not take such a position. He went on to say that "We have all the leverage of suspension. If Brazil does not meet the covenants, we can suspend." A guffaw greeted this remark. Someone said, "Since when have we suspended? The threat is not credible." Stern came in sharply. "I have agreed to suspensions every time they have been recommended by the regions, 
without exception." He went on. "That's the trouble with you guys. You are always trying to second guess me. You are not sending recommendations [for suspension] up. I am not the block." 22

The project proceeded to the phase of negotiations with the Brazilian government. The negotiations, held at Bank headquarters, were unusually long and difficult, taking 10 working days. The two main sticking points were the Bank's covenants on Amerindian protection, which the Brazilians regarded as an issue of national security that foreigners should not be involved in, and the Bank's requirement for an independent monitoring and evaluation capacity, which the Brazilians thought an infringement of government prerogatives.

With negotiations complete, the phase I project went for Board approval in December 1981. At the Board meeting the staff from the Latin America region gave a glowing account. As well as the many benefits that would flow from the removal of infrastructural bottlenecks, they said, the project included "specific environmental protection measures, including an ecological research component designed to help monitor the impact of developmental activities on the natural environment." In addition "the health project would support efforts to control malaria and to improve basic health infrastructure in Rondonia. In conjunction with these projects, the Government was carrying out a special project to safeguard the health and lands of the region's Amerindian population...." Then they gave a brief caution: "despite the mitigating efforts included in the projects, the effort to attempt to guide a spontaneous movement already under way carried many risks [left unspecified]. However, the risks were considerably lower than those which would have existed in the absence of the program [left unspecified]."

The Board resoundingly endorsed the project. Several Board representatives complemented the Bank and the Brazilian government for the excellence of the conception and design. They pointed to the "truly integrated nature and the comprehensive approach to development" demonstrated in the project; and "cited the balance among infrastructure, agriculture, health and even ecology and Amerindian welfare". Said one, "the strategy for harmonious development of the region and opening it to productive settlement was a bold attempt which deserved admiration and substantial external support."

Only one speaker raised worries about the core of the project. "[H]e stressed the risk that if the project were not successful, it could harm the image of the Bank. ... He stressed the necessity of the Bank monitoring the project closely, with periodic progress reports to the Board." Another speaker seconded his remarks. The staff assured them that monitoring and evaluation had been built in. ${ }^{23}$

\footnotetext{
22 As recalled by Stern's assistant, Jane Pratt, interview, March 15, 1995.

${ }^{23}$ Board minutes, dated December 15, 1981, "Loans to Brazil for integrated development of the northwest region”, meeting of December 1, 1981, emphases added.
} 
Unmentioned were the questions raised at the working levels about the basic economic viability of the project, the potential for agriculture in the region, alternative investment sequences, alternative transport modes, alternative regions for agricultural development, and implementation capacity of the federal and state agencies in the region.

Polonoroeste set sail on a raft of assumptions as brittle as they were heroic, or expedient.

Part II of this paper will be published in vol. $36 \mathrm{n}^{\circ} 3$ (144), July-September/2016. 